\title{
Estimation of Tactile Discriminatory Fitness in Hands of Public Transport Drivers
}

Ojashwi Nepal, ${ }^{1}$ Samjhana Thapa, ${ }^{2}$ Roshan Kasti, ${ }^{2}$ Reena Kumari Jha, ${ }^{1}$ Mrigendra Amatya ${ }^{3}$

${ }^{1}$ Department of Physiology, Pre-Clinical Science Complex, Kathmandu University School of Medical Sciences Chaukot, Kavre, ${ }^{2}$ Kathmandu University School of Science, Dhulikhel, ${ }^{3}$ Department of Physiology, Nepal Medical College, Jorpati, Kathmandu Nepal.

\begin{abstract}
Background: Public transport drivers are constantly being exposed to stimuli and are at risk of disorder of peripheral nervous system which can be further complicated by comorbidities. Thus, we wanted to examine intactness of tactile discriminatory ability in healthy drivers by comparing it to healthy samples of non-driving population. Since two point discrimination (TPD) test is frequently used for neurological assessment of tactile stimulation we determined and compared various locations in hands of two populations.
\end{abstract}

Methods: Participants were asked to answer whether they feel one point or two points touch by blunted end of simple compass divider in their hand. The minimum distance between the points at which the participants could answer correctly was noted as two point discrimination value.

Results: Drivers had TPD range of $2-4 \mathrm{~mm}$ with mean $2.53 \pm 0.62$ and, $1-4 \mathrm{~mm}$ with mean $2.6 \pm 0.72$ at middle finger of right and left hand respectively. Following t-test between drivers versus students, significant difference in the mean TPD value in the proximal palm supplied by median nerve $(p=0.016)$ and proximal palm corresponding to ulnar nerve $(\mathrm{p}=0.032)$ on the right hand was found. On the left hand, significant difference in the mean TPD value is found in the proximal palm corresponding to median nerve $(\mathrm{p}=0.008)$ and ulnar nerve $(\mathrm{p}=0.043)$ respectively.

Conclusions: Healthy public transport drivers have less tactile discriminating prowess at proximal palmar surface of hand. Examined distal phalanges and distal palm showed no significant difference in mean of TPD values for healthy drivers versus students.

Keywords: palmar; simple compass divider; two point discrimination.

\section{INTRODUCTION}

Cutaneous receptors send afferent signals for the sensory cortex to appreciate the modality. ${ }^{1,2}$ Thus, examination of tactile integrity excluding emotional component is function of sensory receptors, afferent nerves and sensory cortex. This is appropriately determined through two point discrimination (TPD) test which is frequently used for neurological assessment of tactile stimulation. ${ }^{3}$ Public transport drivers are constantly being exposed to stimuli that can affect their somatosensory reflex and at risk of disorder of peripheral nervous system which can be further complicated by comorbidities. ${ }^{4,5}$ Likewise, public transport drivers in Nepal do not escape the characteristics such as traffic, noise, unmanaged schedules and quality of vehicles. ${ }^{6}$ Early findings that drivers are liable to suffer ill health as a result of job remain true today in Nepal. Thereby, we aimed to compare healthy medical students versus healthy public transport drivers for normative value by two point discrimination test.

\section{METHODS}

A quantitative, cross-sectional study was performed in randomized sample of thirty healthy drivers aged between 20 years and 40 years, operating for transportation of passengers to and from Kathmandu city to Dhulikhel and Bhaktapur for minimum of one year. Protocol approval number of 75/19 was obtained from institutional review committee to conduct the study. Twenty three healthy male students and seven healthy female students of a medical college in Kavrepalanchowk district were tested as control for comparison of TPD value in millimeters (mm). Participants were randomly selected from the pool of drivers and students who matched inclusion criteria and consented for the test. Participants of both the group diagnosed to have neuromuscular disease, skin disease, diabetes, peripheral nervous disorder, infected wound in upper extremities, and upper extremity (unilateral or bilateral) fractures during history elicitation were taken as unhealthy

Correspondence: Dr. Ojashwi Nepal, Department of Physiology, Pre-Clinical Science Complex, Kathmandu University School of Medical Sciences, Chaukot, Kavre, Nepal. Email: Ojashwi@kusms.edu.np. Phone: +977-9851087866. Article received: 2020-01-12. Article accepted: 2020-03-12. 
Nepal et al. Estimation of Tactile Discriminatory Fitness in Hands of Public Transport..

and excluded from inclusion. Palmar side of fingertip at distal phalanx of third and fifth digits along with distal and proximal points in the palm corresponding to median nerve; distal and proximal points in the palm corresponding to ulnar nerve were examined for two point discrimination. Dermatomes examined in fingers include $\mathrm{C} 7$ and C8. Palmar dermatome further includes C6. The test was also performed over the skin surface of forearm. Tested receptive field was five centimeter distal to cubital fossa at the ventral surface of forearm, with dermatome involving C6 and T1. Dermatomes C6 and T1 were not separately examined thus independent result for two separate mentioned fields are not reported and discussed in forearm. A simple compass divider with two blunt limbs was utilized along with meter rule for controlled measurement of two closest points. Subjects were asked to state the touch sensation elicited by pointers of divider. Calibration of two limbs of divider was made before and after the test with help of meter rule and the measurement made was recorded for analysis.

All together, sixty subjects were asked to feel the difference between light touch, pressure, one point pressure and two point pressures before the test was started. They were then asked to shut their eyes, hand was flexed and, held at right angle comfortably by the examiner. Seven different locations mentioned above were tested and, the participants were asked to answer whether they feel one point or two points touch by blunted end of simple divider in their hand. The minimum distance between the points at which the participants could answer correctly was noted as two point discrimination value. The data collected was entered in SPSS (Statistical Package for Social Sciences) version 25 for the analysis. Appropriate tools along with independent sample t-test were utilized to find out the effect of driving on two point discrimination value.

\section{RESULTS}

The average age of total sixty participants was $25.43 \pm 5.81$. The average age (years) of drivers and students was $29 \pm 6.14 \& 21.87 \pm 2.18$ respectively. The average height of 30 drivers and 30 students was $5.53 \pm 0.217 \& 5.47 \pm 0.408$ respectively. The average weight of 30 drivers and 30 students was $64.37 \pm 12.29 \quad \& \quad 63.32 \pm 11.46$ respectively. Measurement unit for weight is in kilogram, height is in feet \& inch.

Table 1 shows t-test for equality of means of BMI in the study population and has $\mathrm{p}=0.165(>0.05)$. There is no difference in body mass index of two populations. Table $2 \&$ Table 3 shows t-test for determining the variation in mean of TPD values between students and drivers. While t-test for
Table 1. T-test for equality of means of Body Mass Index (BMI).

\begin{tabular}{|ccccc|}
\hline Occupation & $\mathbf{N}$ & Mean & SD & P-value \\
Students & 30 & 23.118 & 3.145 & 0.165 \\
Drivers & 30 & 24.039 & 1.691 & \\
\hline
\end{tabular}

\begin{tabular}{|c|c|c|c|c|c|}
\hline \multirow[b]{2}{*}{$\begin{array}{l}\text { Receptive } \\
\text { region on } \\
\text { right hand }\end{array}$} & \multicolumn{2}{|c|}{ Students } & \multicolumn{2}{|c|}{ Drivers } & \multirow[t]{2}{*}{$\begin{array}{l}\text { p- } \\
\text { value }\end{array}$} \\
\hline & $\begin{array}{l}\text { Range } \\
(\mathrm{mm})\end{array}$ & $\begin{array}{l}\text { Mean } \\
\pm \text { SD }\end{array}$ & $\begin{array}{l}\text { Range } \\
(\mathrm{mm})\end{array}$ & $\begin{array}{l}\text { Mean } \\
\pm \text { SD }\end{array}$ & \\
\hline $\begin{array}{l}\text { Third finger } \\
\text { (middle } \\
\text { finger) }\end{array}$ & $1-5$ & $\begin{array}{l}2.4 \pm 0 \\
.77\end{array}$ & $2-4$ & $\begin{array}{l}2.53 \pm \\
0.62\end{array}$ & 0.466 \\
\hline $\begin{array}{l}\text { Fifth finger } \\
\text { (little fin- } \\
\text { ger) }\end{array}$ & $1-5$ & $\begin{array}{l}2.77 \pm \\
0.86\end{array}$ & $2-4$ & $\begin{array}{l}2.7 \pm 0 \\
.75\end{array}$ & 0.75 \\
\hline $\begin{array}{l}\text { Distal me- } \\
\text { dian }\end{array}$ & $2-9$ & $\begin{array}{l}5.9 \pm 1 \\
.69\end{array}$ & $3-11$ & $\begin{array}{l}6.13 \pm \\
1.99\end{array}$ & 0.627 \\
\hline Distal ulnar & $3-9$ & $\begin{array}{l}6.1 \pm 1 \\
.67\end{array}$ & $3-9$ & $6.2 \pm 2$ & 0.834 \\
\hline $\begin{array}{l}\text { Proximal } \\
\text { median }\end{array}$ & $4-10$ & $\begin{array}{l}7.3 \pm 1 \\
.91\end{array}$ & $4-14$ & $\begin{array}{l}8.7 \pm 2 \\
.4\end{array}$ & 0.016 \\
\hline $\begin{array}{l}\text { Proximal } \\
\text { ulnar }\end{array}$ & $4-10$ & $\begin{array}{l}7.27 \pm \\
1.96\end{array}$ & 4-14 & $\begin{array}{l}8.53 \pm \\
2.66\end{array}$ & 0.032 \\
\hline Forearm & $5-21$ & $\begin{array}{l}13.63 \\
\pm 4.11\end{array}$ & $5-25$ & $\begin{array}{l}13.9 \pm \\
4.63\end{array}$ & 0.814 \\
\hline
\end{tabular}

Table 3. Comparison of mean of TPD values between healthy students and drivers on the left hand.

\begin{tabular}{|c|c|c|c|c|c|}
\hline & \multicolumn{2}{|c|}{ Students } & \multicolumn{2}{|c|}{ Drivers } & \multirow{2}{*}{$\begin{array}{l}\text { p- } \\
\text { value }\end{array}$} \\
\hline $\begin{array}{l}\text { Receptive } \\
\text { region on } \\
\text { left hand }\end{array}$ & $\begin{array}{l}\text { Range } \\
(\mathrm{mm})\end{array}$ & $\begin{array}{l}\text { Mean } \\
\pm \text { SD }\end{array}$ & $\begin{array}{l}\text { Range } \\
(\mathrm{mm})\end{array}$ & $\begin{array}{l}\text { Mean } \\
\pm \text { SD }\end{array}$ & \\
\hline $\begin{array}{l}\text { Third finger } \\
\text { (middle } \\
\text { finger) }\end{array}$ & $1-5$ & $\begin{array}{l}2.26 \pm \\
0.73\end{array}$ & $1-4$ & $\begin{array}{l}2.6 \pm 0 \\
.72\end{array}$ & 0.083 \\
\hline $\begin{array}{l}\text { Fifth finger } \\
\text { (little fin- } \\
\text { ger) }\end{array}$ & $1-5$ & $\begin{array}{l}2.4 \pm 0 \\
.77\end{array}$ & $2-4$ & $\begin{array}{l}2.73 \pm \\
0.74\end{array}$ & 0.093 \\
\hline $\begin{array}{l}\text { Distal me- } \\
\text { dian }\end{array}$ & $2-9$ & $\begin{array}{l}5.83 \pm \\
1.56\end{array}$ & $3-11$ & $\begin{array}{l}6.36 \pm \\
2.08\end{array}$ & 0.265 \\
\hline Distal ulnar & $2-9$ & $\begin{array}{l}6.17 \pm \\
1.66\end{array}$ & $3-11$ & $\begin{array}{l}6.43 \pm \\
2.02\end{array}$ & 0.580 \\
\hline $\begin{array}{l}\text { Proximal } \\
\text { median }\end{array}$ & $2-10$ & $\begin{array}{l}7.17 \pm \\
1.64\end{array}$ & $4-14$ & $\begin{array}{l}8.63 \pm \\
2.38\end{array}$ & 0.008 \\
\hline $\begin{array}{l}\text { Proximal } \\
\text { ulnar }\end{array}$ & $5-11$ & $\begin{array}{l}7.57 \pm \\
1.77\end{array}$ & $4-12$ & $\begin{array}{l}8.63 \pm \\
2.19\end{array}$ & 0.043 \\
\hline Forearm & $6-21$ & $\begin{array}{c}13.7 \pm \\
3.77\end{array}$ & $5-25$ & $\begin{array}{l}14.33 \\
\pm 4.83\end{array}$ & 0.574 \\
\hline
\end{tabular}

equality of means were examined, Levene's test found that equal variance can be assumed for all receptive fields except for right palmar proximal ulnar $(p$-value $=0.041)$ and left palmar proximal median ( $p$-value $=0.031)$. These two locations had significance $<0.05$. Thereafter, t-test for equality of means found significant difference in the mean TPD value in the proximal palm corresponding to median nerve $(\mathrm{p}=0.016)$ and proximal palm corresponding to ulnar nerve $(\mathrm{p}=0.032)$ on the right hand. On the left hand significant difference in the 
mean TPD value is seen in the proximal palm corresponding to median nerve $(\mathrm{p}=0.008)$ and ulnar nerve $(\mathrm{p}=0.043)$ respectively.

To compare the TPD values with increasing age, five category of age groups 16-20yrs $(n=7), 21-25$ yrs $(\mathrm{n}=30), 26-30$ yrs $(\mathrm{n}=11), 31-35 \mathrm{yrs}(\mathrm{n}=7) \& 36$ 40 yrs $(n=5)$ including total participants $(n=60)$ with mean \& standard deviation for all tested regions of both hands were analysed through one way ANOVA (Table 4 and Table 5). No significant difference was obtained.

\begin{tabular}{|lllllll|}
\hline \multicolumn{7}{|l}{ Table 4. Comparison for effect of age on TPD among } \\
age groups with one-way ANOVA on right hand.
\end{tabular}

Following t-test for equality of means between TPD value of male $(n=23)$ and female $(n=7)$ students, $p$ value for all points on both right and left hands were $>0.05$. Male and female did not show statistically significant difference in the mean TPD value on every field measured on the hand.

\section{DISCUSSION}

Cutaneous innervation for sensory supply at distal phalanx of middle finger, little finger and, palmar surface are given by the median and ulnar nerves over distributed skin surface of both hands. ${ }^{7} \mathrm{We}$ performed two point discrimination (TPD) test on

\begin{tabular}{|c|c|c|c|c|c|c|}
\hline \multicolumn{7}{|c|}{$\begin{array}{l}\text { Table 5. Comparison for effect of age on TPD among age } \\
\text { groups with one-way ANOVA on left hand. }\end{array}$} \\
\hline \multicolumn{2}{|c|}{$\begin{array}{l}\text { Receptive field on } \\
\text { left hand }\end{array}$} & $\begin{array}{l}\text { Sum of } \\
\text { Squares }\end{array}$ & df & $\begin{array}{c}\text { Mean } \\
\text { Square }\end{array}$ & $\mathbf{F}$ & $\begin{array}{c}\text { p- } \\
\text { value }\end{array}$ \\
\hline \multirow{3}{*}{$\begin{array}{l}\text { Third } \\
\text { finger } \\
\text { (middle } \\
\text { finger) }\end{array}$} & $\begin{array}{l}\text { Between } \\
\text { Groups }\end{array}$ & 4.32 & 4 & 1.08 & 2.09 & \multirow[t]{3}{*}{0.09} \\
\hline & $\begin{array}{l}\text { Within } \\
\text { Groups }\end{array}$ & 28.41 & 55 & 0.52 & 2.09 & \\
\hline & Total & 32.73 & 59 & & 2.09 & \\
\hline \multirow{3}{*}{$\begin{array}{l}\text { Fifth } \\
\text { finger } \\
\text { (little } \\
\text { finger) }\end{array}$} & $\begin{array}{l}\text { Between } \\
\text { Groups }\end{array}$ & 4.19 & 4 & 1.05 & 1.89 & \multirow[t]{3}{*}{0.13} \\
\hline & $\begin{array}{l}\text { Within } \\
\text { Groups }\end{array}$ & 30.54 & 55 & 0.56 & 1.89 & \\
\hline & Total & 34.73 & 59 & & 1.89 & \\
\hline \multirow[t]{3}{*}{$\begin{array}{l}\text { Distal } \\
\text { median }\end{array}$} & $\begin{array}{l}\text { Between } \\
\text { Groups }\end{array}$ & 9.48 & 4 & 2.37 & 0.69 & \multirow[t]{3}{*}{0.60} \\
\hline & $\begin{array}{l}\text { Within } \\
\text { Groups }\end{array}$ & 189.92 & 55 & 3.45 & 0.69 & \\
\hline & Total & 199.40 & 59 & & 0.69 & \\
\hline \multirow[t]{3}{*}{$\begin{array}{l}\text { Distal } \\
\text { ulnar }\end{array}$} & $\begin{array}{l}\text { Between } \\
\text { Groups }\end{array}$ & 17.58 & 4 & 4.40 & 1.32 & \multirow[t]{3}{*}{0.27} \\
\hline & $\begin{array}{l}\text { Within } \\
\text { Groups }\end{array}$ & 183.02 & 55 & 3.33 & 1.32 & \\
\hline & Total & 200.60 & 59 & & 1.32 & \\
\hline \multirow[t]{3}{*}{$\begin{array}{l}\text { Proxima } \\
\text { median }\end{array}$} & $\begin{array}{l}1 \text { Between } \\
\text { Groups }\end{array}$ & 23.38 & 4 & 5.84 & 1.28 & \multirow[t]{3}{*}{0.29} \\
\hline & $\begin{array}{l}\text { Within } \\
\text { Groups }\end{array}$ & 252.03 & 55 & 4.58 & 1.28 & \\
\hline & Total & 275.40 & 59 & & 1.28 & \\
\hline \multirow[t]{3}{*}{$\begin{array}{l}\text { Proxima } \\
\text { ulnar }\end{array}$} & $\begin{array}{l}1 \text { Between } \\
\text { Groups }\end{array}$ & 15.26 & 4 & 3.82 & 0.90 & \multirow[t]{3}{*}{0.47} \\
\hline & $\begin{array}{l}\text { Within } \\
\text { Groups }\end{array}$ & 232.14 & 55 & 4.22 & 0.90 & \\
\hline & Total & 247.40 & 59 & & 0.90 & \\
\hline \multirow[t]{3}{*}{ Forearm } & $\begin{array}{l}\text { Between } \\
\text { Groups }\end{array}$ & 66.48 & 4 & 16.62 & 0.89 & \multirow[t]{3}{*}{0.48} \\
\hline & $\begin{array}{l}\text { Within } \\
\text { Groups }\end{array}$ & 1028.50 & 55 & 18.70 & 0.89 & \\
\hline & Total & 1094.98 & 59 & & 0.89 & \\
\hline
\end{tabular}

palmar surface of both hands over receptive regions supplied by ulnar and median nerves in drivers and compared TPD values with non-driver control, medical students, in our study. This study is first to attempt two point discrimination (TPD) test in sample population of healthy public transport drivers in Nepal. This further is compared to normal values of students in health.

We have reported normative data in sample population and, assessed it to observe possible alteration between control versus drivers. Control value recorded in fingertips of middle finger and little finger in student population for right hand ranges $1-5 \mathrm{~mm}$ with mean and standard deviation of $2.4 \pm 0.77$ and $2.77 \pm 0.86$ respectively. As per the referred values by American society of hand therapists for palm and finger of hand $<6 \mathrm{~mm}$ is 'normal' and $>11 \mathrm{~mm}$ is 'poor'. In between values of $6 \mathrm{~mm}$ to $10 \mathrm{~mm}$ are said to be 'fair' for static two point discrimination scoring. ${ }^{8}$ The mean of normative values obtained for fingertips of middle 
and little fingers on control and drivers were within normal range, $<6 \mathrm{~mm}$ on both hands. Left hand normative value in same population for tips of middle finger and little finger ranges from 1-5 mm with average of $2.27 \pm 0.74$ and $2.4 \pm 0.77$ respectively. This is in accord with findings illustrated by Alsaeed et. al. in 270 healthy female students aged between 20-23 years of art \& design, medical and literary backgrounds of Princess Noura Bint Abdulrahman University in Riyadh. Though our study includes 23 male medical students, the values mentioned closely matches to the reported figures in the study. ${ }^{8}$

Intragroup analysis of TPD value was done between male $(n=23)$ and female $(n=7)$. They did not show statistically significant difference in the mean TPD value on sites measured on the hand. This is different to a study performed in 256 college students in their twenties attending $\mathrm{N}$ university in Chonan, Republic of Korea where females showed TPD in shorter distance than in males. They used a three point aesthesiometer and measured the TPD value. ${ }^{9}$ Due to lack of proportionate numbers of genders included for comparison the finding reported by our study needs to be revisited with appropriate sampling for definite conclusions. Hence we do not attempt to contradict the findings where females have shorter distance than male in TPD abilities. However, a study made in Indian population including 50 subjects, 25 men and 25 women with age group 18-28 years utilizing an aesthesiometer concluded no difference in two point discrimination abilities between genders. The study has reported TPD of $41.3 \pm 1.1 \mathrm{~mm}$ in the upper lateral arm to $2.4 \pm 0.1 \mathrm{~mm}$ in the palmar surface of distal phalanx of little finger. ${ }^{10}$

Our findings in drivers aged between 20-40 years had the normal mean of TPD values as found in fingertips to that for students. It has been reported advancing age increases the TPD value. ${ }^{11}$ A study conducted in one hundred forty six healthy adults representing community in south eastern Nigeria in Abia state University with age distribution of 18-55 years utilizing meter rule and, blunt divider have found increasing value of two point threshold in, thumb of upper limbs with increasing age. ${ }^{12} \mathrm{We}$ found no such increment compared between young students to drivers in locations of fingertips supplied by median and ulnar nerves. As has been shown in table 4, age does not affect the TPD values in examined local sample population of Nepal. Age distribution of sixty subjects was limited to difference of twenty years and the difference is not apparent in our study. Moreover, all subjects had sound capacity to discriminate and localize light touch, pressure sense and one point localization. There was significant increase in the mean TPD value of proximal palm in both right (median; 8.7 $\pm 2.4 \&$ ulnar; $8.53 \pm 2.66$ ) and left (median; $8.63 \pm 2.38 \&$ ulnar $8.63 \pm 2.19$ ) hands of the drivers than that of the students. Proximal palmar surface supplied by ulnar and median nerves of both the right and left hands respectively had less discriminative ability with larger TPD value in proximal palmar surface of public transport drivers than in students. There is significant evidence of difference in discriminating abilities in the proximal palmar surface of both hands in public transport drivers compared to healthy students. This raised TPD value is due to loss of palmar tactile sensibility and is not due to effect of age in drivers. The values recorded had range starting from 4 millimeters exceeding 11 millimeters on both hands at proximal palmar surface. However, the increased mean value for the range of TPD remained within fair range for these receptive fields in drivers without alarm. Other points on the hand, distal palm and forearm, showed slight increase in TPD values in drivers than that of student but these values did not make statistically significant.

According to Gellis \& Pool, TPD is best in the hand and forearm during the third decade of life. ${ }^{13}$ However, tactile discriminating ability was uniformly lesser with larger two points distance in forearm versus distal parts of upper limbs in both groups, in our study. Raised distance for perceived two points over surface of forearm versus phalanges and distal palmar locations is also reported in literature as per finding of this study. ${ }^{8-10}$ Public transport drivers in Nepal are not in habit of wearing protective gloves while driving vehicles. Glabrous skin of thenar and hypothenar eminence is under mechanical pressure during long hours of work at steering wheel which can alter the function of low threshold mechanoreceptors. This may result into increased distance for two point discrimination. Moreover, haptic safety features of vehicles targeted through both eminences of hands may not be suitable for these drivers.

\section{CONCLUSIONS}

Receptive fields over surface of proximal palm are less sensitive for tactile discrimination in drivers. Healthy public transport drivers have less tactile discriminating prowess at proximal palmar surface of hand. This warrants further inquiry in somatosensory health of public vehicle drivers at work in Nepal. Normative value for TPD is established in sample population of Nepal through recordings obtained in healthy medical students. Two point discrimination (TPD) test can be performed in minimally facilitated lab without temperature controlled set up, utilizing simple compass divider and meter rule. With minimal precautions, avoiding pain infliction in subjects, the procedure is tangible for larger population study in the community. 


\section{REFERENCES}

1. D. M. Owens, E. A. Lumpkin. Diversification and Specialization of Touch Receptors in Skin. Cold Spring Harb Perspect Med 2014;4:a013656. https://doi=10.1101/ cshperspect.a013656

2. Ackerley R, Carlsson I, Wester H, Olausson H and Backlund Wasling $\mathrm{H}$. Touch perceptions across skin sites: differences between sensitivity, direction discrimination and pleasantness. $\quad$ Front. Behav. Neurosci. 2014;8:54. doi: 10.3389/ fnbeh.2014.00054

3. Won SY, Kim HK, Kim ME, Kim KS. Twopoint discrimination values vary depending on test site, sex and test modality in the orofacial region: a preliminary study. J Appl Oral Sci. 2017 Jul-Aug;25(4):427-435. doi: 10.1590/1678 -7757-2016-0462. PMID: 28877282; PMCID: PMC5595116.

4. Tse JLM, Flin R, Mearns K. Bus Driver WellBeing Review: 50 Years of Research. Transportation Research Part F: Traffic Psychology and Behaviour. 2006; 9(2):89114.http://www.sciencedirect.com/science/ journal/13698478

5. Cho SC, Rama A, Kim BJ, Roh H, Park J, Katz J. et. al. Driving with polyneuropathy. Muscle \& Nerve. 2009;41(3):324-328.DOI 10.1002/ mus. 21511.

6. GoN Ministry of physical planning, works and transport management. Nepal road safety action plan 2013-2020. 2013 Feb:1-32.

7. Rapp FA, Soos MP. Anatomy, Shoulder and Upper Limb, Hand Cutaneous Innervation. [Updated 2019 Jun 21]. In: StatPearls [Internet]. Treasure Island (FL): StatPearls Publishing; 2020 Jan. Available from: https://
www.ncbi.nlm.nih.gov/books/NBK544247/

8. Alsaeed, S., Alhomid, T., Zakaria, H., Alwhaibi, R. Normative values of two-point discrimination test among students of princess noura bint abdulrahman university in Riyadh. International Journal of Advanced Physiology and Allied Sciences. 2014; 1(1):42-52. http:// medical.cloud-journals.com/index.php/IJAPAS/ article/view/Med-186

9. Koo JP, Kim SH, An HJ, Moon OG, Choi JH, Yun YD, Park JH, Min KO. Two-point discrimination of the upper extremities of healthy Koreans in their 20's. J Phys Ther Sci. 2016 Mar;28(3):870-4. doi: 10.1589/ jpts.28.870. Epub 2016 Mar 31. PMID: 27134375; PMCID: PMC4842456.

10. Shibin, K. \& Samuel, A. J. The discrimination of two-point touch sense for the upper extremity in indian adults. Int. J. Health Rehabil. Sci. 2013;2(1):38-43.

11. Evaluation of normal values for stationary and moving two-point discrimination in the hand. Louis D.S., Greene T.L., Jacobson K.E., Rasmussen C., Kolowich P., Goldstein S.A. Journal of Hand Surgery. 1984;9(4):552555. DOI:10.1016/s0363-5023(84)80109-4

12. Oparah SK, Ubani CD, Osim EE. Assessment of two point discrimination threshold on the thumbs of healthy adult Nigerians. Sch. J. App. Med. Sci. 2016 Jan; 4(1A):15-19. ISSN 2320669.

13. Gellis M, Pool R. Two-point discrimination distances in the normal hand and forearm: application to various methods of fingertip reconstruction. Plastic and Reconstructive Surgery. $\quad 1977 ; 59(1)$ : 57-63.

Citation: Nepal O, Thapa S, Kasti R, Jha RK, Amatya M. Estimation of Tactile Discriminatory Fitness in Hands of Public Transport Drivers. JCMS Nepal. 2020; 16(1):1-5. 